\title{
IMPACT OF EXTRA CURRICULAR TRAINING (BASKETBALL AND ATHLETICS) ON MUSCLE STRENGTH IN BOYS 11-14 YEARS OF AGE
}

\author{
Arūnas Emeljanovas', Kristina Poderienè ${ }^{1}$, Dario Novak ${ }^{2}$ \\ Lithuanian Academy of Physical Education ${ }^{1}$, Kaunas, Lithuania \\ University of Zagreb ${ }^{2}$, Zagreb, Croatia
}

\begin{abstract}
Research background and hypothesis. Human growth and maturation is determined by interaction of endogenous and exogenous factors. The most sensitive to the external influences is the age period between 11 and 14 years. The investigations of this age period in boys engaged in sports may reveal the complex interaction of the endogenous and exogenous factors. Hypothesis: Improvement of the muscle capacity indices in early adolescence depends on the nature of physical load.

Research aim was to examine long-term extra curricular training in basketball games and athletics (sprint) effects on muscle strength of boys in early adolescence.

Research methods. 105 boys - non-athletes $(n=35)$, athletes - sprint runners $(n=35)$ and basketball players $(n=35)$ - participated in the study. The boys were engaged in the chosen sports for no less than 2 years. The same cohorts were followed for four years at the age of 11, 12, 13 and 14 years. The strength of the arm levators, femoral flexors, calf extensors, calf flexors, forearm extensors and forearm flexors was measured using the dynamometer "Nicholas". The maximum force required for the isometric muscle contraction mode was obtained when the resistance, caused by the investigator, occurred.

Research results. Dynamometry assessments between the groups showed that the muscle strength of the athletes - sprint runners was greater than that of non-athletes and basketball players. Statistically significant differences between boys were identified in all age groups in assessment of both right and left sides.

Discussion and conclusions. Improvement of the muscle capacity indices in early adolescence depends on the nature of physical load: the muscle strength indices increased more in the athletes - sprint runners than in the basketball players.
\end{abstract}

Keywords: adolescence, dynamometry, sport.

\section{INTRODUCTION}

$\mathrm{H}$ uman growth and maturation is determined by interaction of endogenous and exogenous factors (Armstrong, Welsman, 2005). A significant role in this interaction is given to the exogenous factors, i. e. physical activity, the nature of physical load and other physical load characteristics (Szopa, Žychowska, 2001).

A number of epidemiological studies have already highlighted the positive effects of physical exercise on the working capacity and functional state of skeletal muscles and cardiovascular system
(Strong et al., 2005; Hilberg, 2008). Regular participation in training sessions of a particular sport for a long time during childhood and adolescence is a significant factor of the prevalence of the nature of physical exercises (Pearson et al., 2006). The most sensitive age to the external influences is the age period between 11 and 14 years. Therefore the investigations of this age period in boys engaged in sports may reveal the complex interaction of the inherent and acquired (endogenous and exogenous) factors. Reports and case studies on this issue are 
still insufficient grounds for drawing conclusions about the safety of intense training or high-level competition in young athletes (American Academy of Pediatrics - further AAP, 2010). Hypothesis: Improvement of the muscle capacity indices in early adolescence depends on the nature of physical load.

The aim of the study was to examine long-term extra curricular training effects on muscle strength of basketball players and athletes - sprint runners and non-athletes boys in early adolescence.

\section{RESEARCH METHODS}

Subjects. The sample consisted of 105 boys, 11 years of age at the beginning of the research, Lithuanian high school and sports school students. All subjects were divided into three groups: nonathletes $(\mathrm{n}=35)$, athletes - sprint runners $(\mathrm{n}=35)$ and basketball players $(\mathrm{n}=35)$. The study involved the boys engaged in the chosen sports not less than 2 years. The same boys were followed for four years and took part in the study at the age of 11,12 , 13 and 14 years (Table).

Research methods and organization. The measurements were carried out at the Kinesiology Laboratory, Lithuanian Academy of Physical Education and started in spring 2006 (April/May). The protocol of the study was approved by Local Ethics Committee. All tests and measurements were performed at the same time of the day during all four years of the study. Two days before testing the boys did not perform any all-out exercise.

Muscle strength was measured using the dynamometer "Nicholas" (Lafayette Instruments
Company, Lafayette, Indiana). The maximum force required for the isometric muscle contraction mode was obtained when the resistance caused by the investigator occurred. The dynamometer measured strength range between 0 and $199.9 \mathrm{~kg}$, therefore, it was possible to assess the major muscles strength. The strength of the arm levators, femoral flexors, calf extensors, calf flexors, forearm extensors and forearm flexors was measured. The measurements were repeated three times and the best score was registered.

Data processing methods. The obtained data were processed by descriptive statistics methods. In order to evaluate the significance of the obtained differences between the groups one-way analysis of variance - ANOVA (Student's test summary of several independent samples) was used. The differences between the measured values were statistically significant at the level of $p<0.05$.

\section{RESEARCH RESULTS}

Intergroup significant differences were found in forearm elevators strength in the time point of 12 years of age between the non-athletes and both groups of athletes (both the left and right arms); in the time point of 13 years of age - between the non-athletes and athletes - sprint runners (both the left and right arms); in the time point of 14 years of age - between all the three groups (the right arm) and between both groups of sportsmen and the non-athletes (the left arm) (Figure 1).

Significant differences in femoral flexors strength were found: in the time point of 13 years of age - between the athletes - sprint runners,
Table. Basic anthropometric characteristics of subjects

\begin{tabular}{|c|c|c|c|}
\hline Age & Sport event & Body height, cm & Body mass, kg \\
\hline \multirow{3}{*}{11 years } & Non-athletes $(\mathrm{n}=35)$ & $150.3 \pm 2.2$ & $42.6 \pm 3.4$ \\
\hline & Athletes sprint runners $(\mathrm{n}=35)$ & $149.1 \pm 2.5$ & $40.2 \pm 2.6$ \\
\hline & Basketball players $(n=35)$ & $154.1 \pm 2.1$ & $43.2 \pm 2.4$ \\
\hline \multirow{3}{*}{12 years } & Non-athletes $(\mathrm{n}=32)$ & $158.6 \pm 1.8$ & $46.6 \pm 1.8$ \\
\hline & Athletes sprint runners $(\mathrm{n}=21)$ & $159.4 \pm 2.2$ & $45.4 \pm 2.4$ \\
\hline & Basketball players $(n=19)$ & $162.2 \pm 2.4$ & $47.8 \pm 2.4$ \\
\hline \multirow{3}{*}{13 years } & Non-athletes $(\mathrm{n}=30)$ & $165.7 \pm 2.4$ & $54.5 \pm 2.1$ \\
\hline & Athletes sprint runners $(\mathrm{n}=18)$ & $166.1 \pm 1.9$ & $51.2 \pm 2.2$ \\
\hline & Basketball players $(\mathrm{n}=17)$ & $169.6 \pm 1.9$ & $53.5 \pm 2.2$ \\
\hline \multirow{3}{*}{14 years } & Non-athletes $(\mathrm{n}=26)$ & $171.9 \pm 1.6$ & $61.5 \pm 2.3$ \\
\hline & Athletes sprint runners $(\mathrm{n}=15)$ & $170.9 \pm 1.9$ & $56.2 \pm 2.0$ \\
\hline & Basketball players $(n=16)$ & $175.2 \pm 2.4$ & $58.9 \pm 2.5$ \\
\hline
\end{tabular}


basketball players and non-athletes (both the left and right leg); in the time point of 14 years of age between all the three groups (the right leg), between non-athletes boys and athletes - sprint runners (the left leg) (Figure 2).
Calf extensors strength scores showed significant differences: in the time point of 12 years of age between the athletes - sprint runners, basketball players and non-athletes (both the left and right leg); in the time point of 13 years of age -
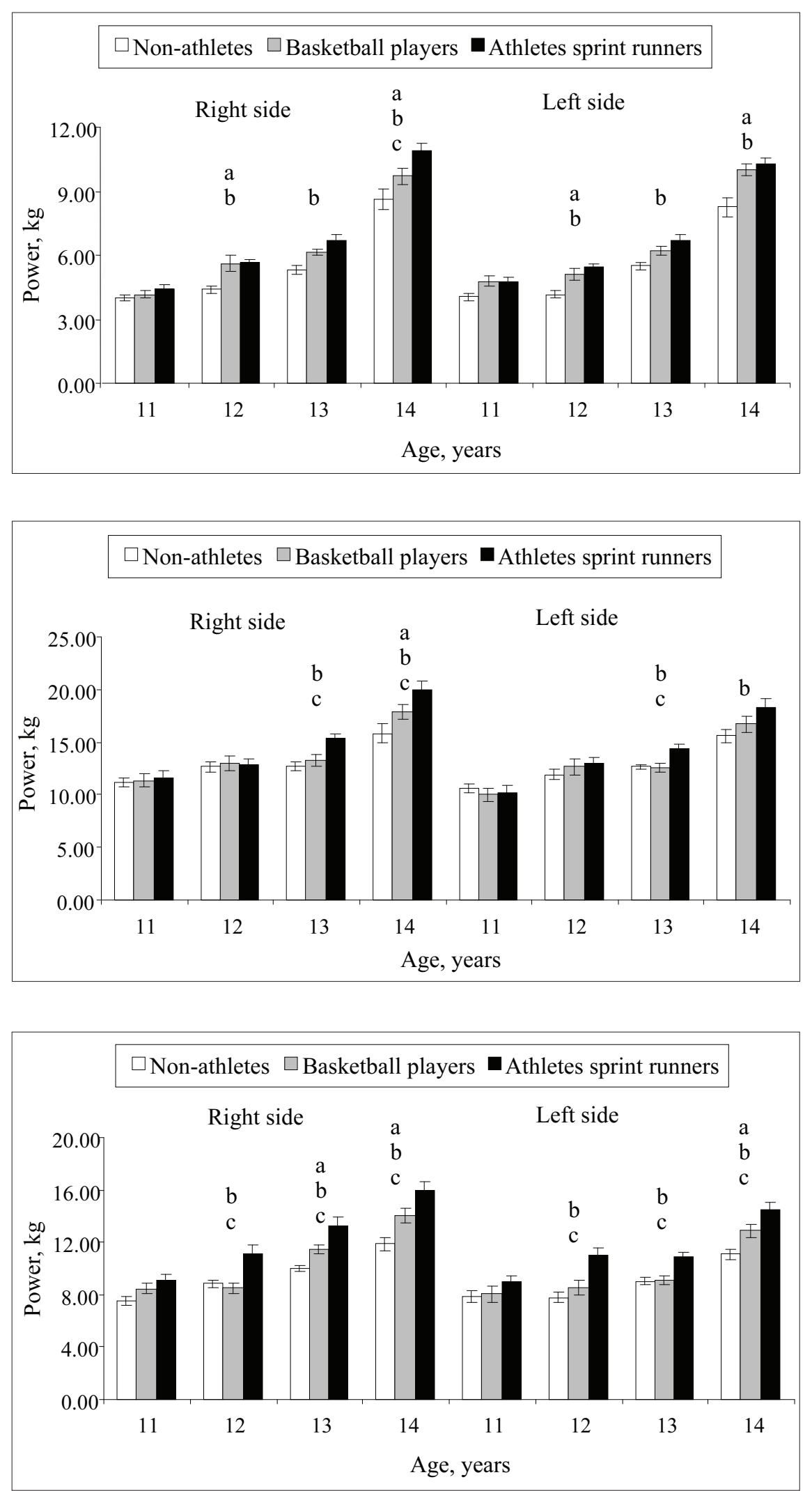

Figure 1. The results of arm levators strength in the non-athletes, sport basketball players and athletes sprint runners

Note. The difference between: the nonathletes and basketball players - a, the athletes sprint runners and nonathletes $-b$, the basketball players and athletes sprint runners - c; statistically significant at $\mathrm{p}<0.05$.

Figure 2. The results of femoral flexors strength in the non-athletes, basketball players and athletes sprint runners

Note. The difference between: the nonathletes and basketball players - a, the athletes sprint runners and nonathletes - b, the basketball players and athletes sprint runners $-\mathrm{c}$; statistically significant at $\mathrm{p}<0.05$.

Figure 3. The results of calf extensors strength in the non-athletes, basketball players and athletes sprint runners

Note. The difference between: the nonathletes and basketball players - a, the athletes sprint runners and nonathletes $-b$, the basketball players and athletes sprint runners $-\mathrm{c}$; statistically significant at $\mathrm{p}<0.05$. 
between all the three groups (the right leg), and between the athletes - sprint runners, basketball players and the non-athletes (the left leg); in the time point of 14 years of age - in all the three groups (both the left and right leg) (Figure 3). Intergroup comparison of calf flexors' strength showed the significant differences: in the time points of 12 and 13 years between the athletes - sprint runners, basketball players and the non-athletes (both the left and right leg); in the time point of 14 years between the groups of athletes - sprint runners and non-athletes (the right leg) and between all the three groups (left leg) (Figure 4).
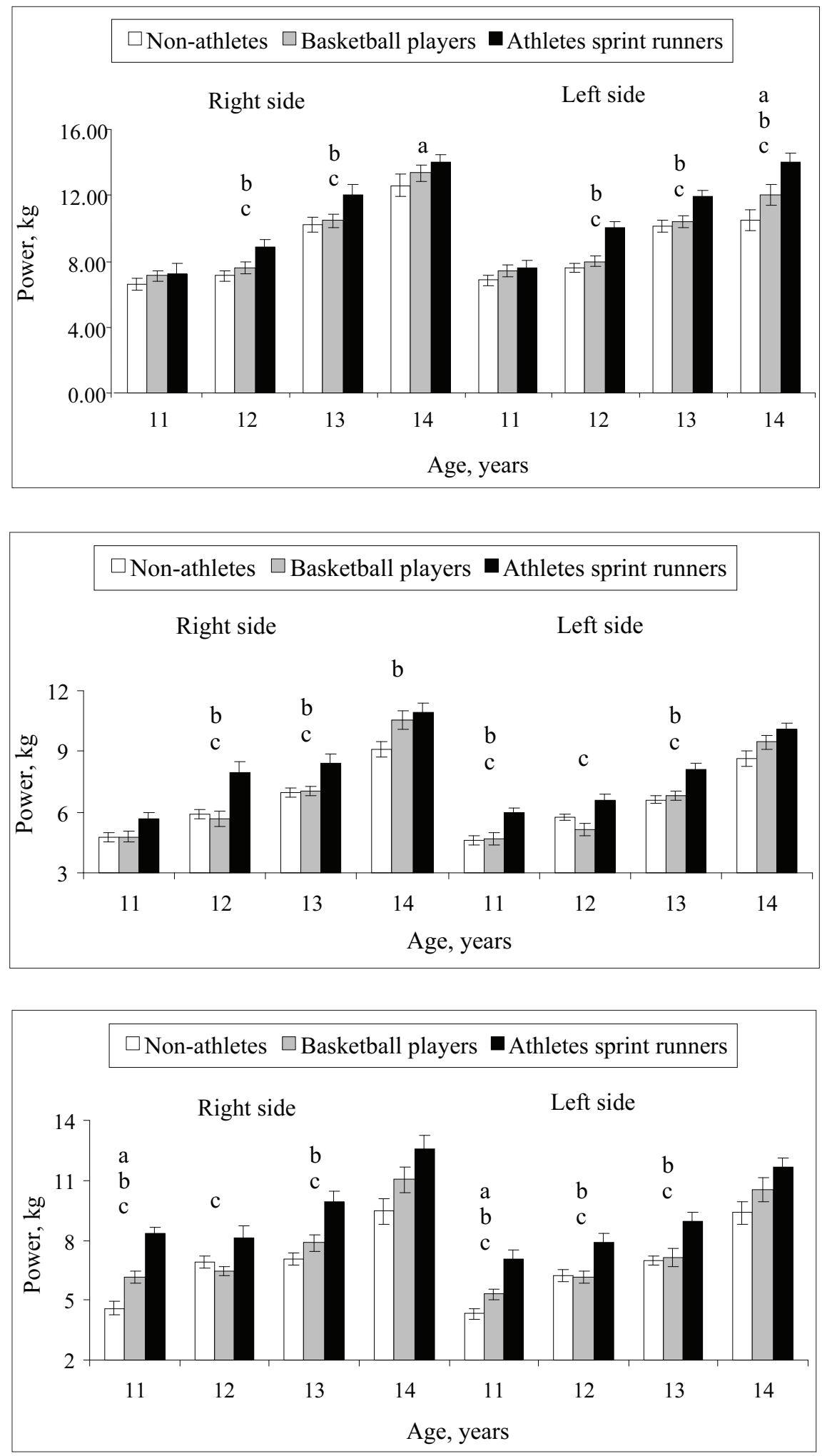

Figure 4. The results of calf flexors strength in the non-athletes, basketball players and athletes sprint runners

Note. The difference between: the nonathletes and basketball players - a, the athletes sprint runners and non-athletes b, the basketball players and athletes sprint runners - c; statistically significant at $\mathrm{p}<0.05$.

Figure 5. The results of forearm extensors strength in non-athletes, basketball players and athletes sprint runners

Note. The difference between: the nonathletes and basketball players - a, the athletes sprint runners and nonathletes $-b$, the basketball players and athletes sprint runners - c; statistically significant at $\mathrm{p}<0.05$.

Figure 6 . The results of forearm flexors strength in non-athletes, basketball players and athletes sprint runners

Note. The difference between: the nonathletes and basketball players - a, the athletes sprint runners and nonathletes $-b$, the basketball players and athletes sprint runners - c; statistically significant at $\mathrm{p}<0.05$. 
Measurements of forearm flexors strength in 11-14 years of age, as well as the best results achieved in athletes - sprint runners group, and statistically significant difference compared with the results of non-athletes and basketball players group (Figure 5). The same situation was observed in the evaluation of forearm extensors strength right side and left side of 11 and 13 years of age groups (Figure 6).

Dynamometry assessments between the groups showed that the muscle strength of the athletes sprint runners was greater than non-athletes and basketball players. Statistically significant differences between boys were identified in all age groups in assessment of both: right and left sides.

\section{DISCUSSION}

Response of human body to regular physical exercise, affecting the body growth and development features, manifests itself as impact on the functional and morphological changes in the bodily systems (Gilbert, 2000; Lodish et al., 2000). The most sensitive age to the external influences is age period between 11 and 14 years. Therefore the investigations of this age period in boys engaged in sports may reveal the complex interaction of the inherent and acquired (endogenous and exogenous) factors. Reports and case studies on this issue are still insufficient grounds for drawing conclusions about the safety of intense training or high-level competition in young athletes (AAP, 2010).

The present study has evaluated longitudinal impact of basketball game and athletics (sprint) on the features of development dynamics of muscular strength in boys from 11 to 14 years of age. It has shown that the nature of physical load (partially regulated in basketball game-specific activities and strictly regulated physical load in sprint training sessions) differently affects the features of CVS and muscles strength development in growing and rapidly evolving body (Pearson et al., 2006).

Although better results of the results of dynamometric strength assessments and intergroup comparison showed that muscle strength was more specific to the athletes sprint runners than to the non-athletes and basketball games players. Such significant differences between boys were identified at all the age points and in the assessments of both the right and the left side. Muscle capacity assessment data confirmed findings of a number of other authors claiming that exercise affects the growth and development processes (Macera et al., 2003; Myers et al., 2004).

A large number of studies has been done in order to assess growth and development patterns (McCarthy et al., 2002; Munchmeier, 2001) and to find the most appropriate physical load (Docherty, 2002; Wolpert et al., 2003). Generalization of results of previous studies and of this study suggest that interaction of the external and internal factors determine properties of muscular development and its expression during exercise in the 11-14-year-old boys.

Precisely regulated physical load, specific to the cyclic sports, is an external factor influencing boys' muscle strength parameters in the period of 11-14 years of age.

These results are in concordance with the previous findings of other authors (Pearson et al., 2006; Krustrup et al., 2010), where diversely directed physical loads, creating different external and internal stimuli relations, lead to different adaptation properties. Thus, due to regular physical loads exposure, but of different nature, the functional state of muscular system of athletes in sprint training sessions improves faster.

To sum up, it is necessary to take into account the fact that the athletes' physical maturity and functional ability indicators are also the outcome of the selection process and adaptation dynamics (Philippaerts et al., 2006; Vaeyens et al., 2008). It is well known that the initial functional readiness of a child is an important factor in choosing the kind of sports activities and in sports selection as well. Nevertheless, our study confirms previous research findings (Strong et al., 2005; Baquet et al., 2006; Horst et al., 2007; Emeljanovas, Poderys, 2010) that sports activities unquestionably have a considerable influence on the capabilities of skeletal muscles.

\section{CONCLUSION AND PERSPECTIVES}

Improvement of the muscle capacity indices in early adolescence depends on the nature of physical load: the muscle strength indices increased more in the athletes - sprint runners than in the basketball players. 


\section{REFERENCES}

American Academy of Pediatrics. (2010). AAP Policy Statement: Intensive Training and Sports Specialization in Young Athletes. Committee on Sports Medicine and Fitness. Pediatrics, 125 (2), 444-445.

Armstrong, N., Welsman, J. (2005). Physiology of the child athlete. Children's Health and Exercise Research Centre, 92 (4), 2368-2379.

Baquet, G., Twisk, J. W., Kemper, H. C., Van Praagh, E., Berthoin, S. (2006). Longitudinal follow-up of fitness during childhood: Interaction with physical activity. American Journal of Human Biology, 18 (1), 51-58.

Docherty, D. (2002). The effects of accentuated eccentric loading on strength, muscle hypertrophy, and neural adaptations in trained individuals. Journal of Strength Conditioning and Response, 16 (1), 25-32.

Emeljanovas, A., Poderys, J. (2010). Sportinių žaidimų ir cikliniu sporto šaku pratybu poveikis 11-14 metų berniukų funkciniam parengtumui. Ugdymas. Kūno kultūra. Sportas, 1 (76), 29-36.

Gilbert, R. W. (2000). Blood flow rate effects in continuous venovenous hemodiafiltration on blood urea nitrogen and creatinine reduction. Journal of Nephrology Nursing, 27 (5), 503-506.

Hilberg, T. (2008). Physical activity in the prevention of cardiovascular diseases: Epidemiology and mechanisms. Hamostaseologie, 28 (1), 9-15.

Horst, K., Paw, J. C. A, Twisk, J. W. R., Mechelen, W. (2007). A brief review on correlates of physical activity and sedentariness in youth. Medicine and Science in Sport and Exercise, 39 (8), 1241-1250.

Krustrup, P., Christensen, J. F., Randers, M. B. et al. (2010). Muscle adaptations and performance enhancements of soccer training for untrained men. European Journal of Applied Physiology, 108 (6), 1247-1258.

Lodish, H. F., Blobe, G. C., Schiemann, W. P. (2000). Role of transforming growth factor beta in human disease. North England Journal of Medicine, 4 (18), $1350-1358$.
Macera, C. A., Hootman, J. M., Sniezek, J. E. (2003). Major public health benefits of physical activity. Arthritis Rheumathology, 49, 122-128.

McCarthy, J. P., Pozniak, M. A., Agre, J. C. (2002). Neuromuscular adaptation to concurent strength and endurance training. Medicine Science and Sports Exercise, 34 (3), 511-519.

Munchmeier, R. (2001). Growing up in changing conditions on the structural change of childhood and adolescence. Praxis der Kinderpsychologie und Kinderpsychiatrie, 50 (2), 119-134.

Myers, J., Kaykha, A., George, S. et al. (2004). Fitness versus physical activity patterns in predicting mortality in men. American Journal of Medicine, 117, 912-918.

Pearson, D. T., Naughton, G. A., Torode, M. (2006). Predictability of physiological testing and the role of maturation in talent identification for adolescent team sports. Journal of Science in Medicine and Sport, 9 (4), 277-287.

Philippaerts, R. M., Vaeyens, R., Janssens, M. et al. (2006). The relationship between peak height velocity and physical performance in youth soccer players. Journal of Sports Science, 24 (3), 221-230.

Strong, W. B., Malina, R. M., Blimkie, C. J. R. et al. (2005). Evidence based physical activity for school-age youth. Journal of Pediatrics, 146 (6), 732-737.

Szopa, J., Žychowska, M. (2001). Treniruotumas ir genetiniai gabumai. Ugdymas. Kūno kultūra. Sportas, 2 (39), 63-69.

Vaeyens, R., Lenoir, M., Williams, A. M., Philippaerts, R. M. (2008). Talent identification and development programmes in sport: Current models and future directions. Sports Medicine, 38 (9), 703-714.

Wolpert, D. M., Doya, K., Kawato, M. (2003). A unifying computational framework for motor control and social interaction. Philosophical Transactions. Biological Sciences, 358, 593-602. 


\title{
KREPŠINIO IR LENGVOSIOS ATLETIKOS PRATYBŲ POVEIKIS 11-14 METŲ BERNIUKŲ RAUMENŲ JĖGAI NEFORMALAUS FIZINIO UGDYMO METU
}

\author{
Arūnas Emeljanovas ${ }^{1}$, Kristina Poderienè ${ }^{1}$, Dario Novak ${ }^{2}$ \\ Lietuvos kūno kultūros akademija ${ }^{1}$, Kaunas, Lietuva \\ Zagrebo universitetas ${ }^{2}$, Zagrebas, Kroatija
}

\begin{abstract}
SANTRAUKA
Tyrimo pagrindimas ir hipotezė. Žmogaus augimą ir brendimą lemia vidinių ir išorinių veiksnių sąveika. Labiausiai išoriniams veiksniams jautrus yra 11-14 metų amžiaus tarpsnis. Šio amžiaus sportuojančių berniukų kompleksinès būklès tyrimai gali atskleisti sudètingą endogeninių ir egzogeninių veiksnių sąveiką. Hipotezè: paauglystèje raumenų pajègumo rodiklių gerèjimas priklauso nuo fizinio krūvio pobūdžio.

Tikslas - nustatyti ilgalaikio neformalaus fizinio ugdymo (krepšinio žaidimo ir lengvosios atletikos (trumpuju nuotolių bėgimo)) pratybų poveiki paauglių raumenų jègai.

Metodai. Buvo tirti 105 berniukai: nesportuojantieji $(\mathrm{n}=35)$, lengvaatlečiai (sprinteriai, $\mathrm{n}=35$ ) ir krepšininkai $(\mathrm{n}=35)$, lankantys pratybas ne mažiau kaip dvejus metus. Tie patys respondentai buvo tiriami ketverius metus iš eilès, t. y. kai jiems buvo 11, 12, 13 ir 14 metų. „Nicholas“ dinamometru buvo matuojama pasirinktų raumenu (rankos keliamujų ir šlaunies lenkiamujų, blauzdos tiesiamujų ir lenkiamuju, dilbio tiesiamujų ir lenkiamuju) grupiu jèga. Tyrẻjui sukèlus pasipriešinimą, buvo matuojama didžiausia izometrinio raumenų susitraukimo jëga.

Rezultatai. Dinamometrija tiriamujų grupèse parodè, kad lengvaatlečiu (sprinterių) raumenų jèga buvo didesnè nei krepšininkų ir nesportuojančiu berniukų. Statistiškai patikimi skirtumai tarp berniukų grupių rodiklių buvo aptikti visais tirtais amžiaus tarpsniais matuojant tiek kairès, tiek dešinės pusès raumenis.

Aptarimas ir išvada. Paauglystèje raumenų pajègumo rodiklių gerèjimas priklauso nuo fizinio krūvio pobūdžio: lengvaatlečių (sprinto bėgikų) raumenų jèga tiriant buvo didesnè nei krepšininkų.
\end{abstract}

Raktažodžiai: paauglysté, dinamometrija, sportas.

Gauta 2011 m. lapkričio 9 d.

Received on November 9, 2011 